\title{
KULT STALINA W KALEJDOSKOPIE
}

\section{JAN PLAMPER \\ KULT STALINA. STUDIUM ALCHEMII WŁADZY}

Jakub Bazyli Motrenko

Uniwersytet Warszawski

We wstępie do swojej książki Jan Plamper posługuje się kilkoma anegdotami, żeby wprowadzić czytelnika w fenomen kultu Józefa Stalina. Jedna z nich mówi o tym, jak syn radzieckiego dyktatora Wasilij wykorzystał swoje nazwisko, aby uniknąc kary po jakiejś pijackiej awanturze, co spotkało się z dużą dezaprobatą ojca:

- Ale ja też nazywam się Stalin - odparował Wasilij.

- Nie - powiedział Stalin - Ty nie jesteś Stalin i ja też nie jestem Stalin. Stalin to władza radziecka. Stalin to postać z gazet i portretów, nie ty, ani nawet nie ja! (Plamper 2014: 15)

Celem książki jest demistyfikacja kultu i nadanie mu historycznego wymiaru. Autor, posługując się instrumentarium historyka, socjologa i historyka sztuki, stara się wyjaśnić jego genezę i sens: „Głównym tematem tej książki stało się zbadanie, jak nabierał znaczenia symboliczny wymiar Stalina - jak powstał jego kult - i jak rozpowszechniano wytwory kultu, oraz jak ludzie nadawali im sens" (tamże: 345).

Książka dzieli się na dwie zasadnicze części: wytwory kultu (są to dwa rozdziały - o przedstawieniach Stalina na fotografiach i rycinach w dzienniku „Prawda” oraz w malarstwie) i tworzenie kultu (trzy rozdziały o patronacie w sztuce, instytucjach organizujących tworzenie sztuki i publiczności). Do tego dochodzi wstępny rozdział o historii nowoczesnego kultu jednostki. Wytwory analizowane są w porządku chronologicznym (analiza diachroniczna publikacji w „Prawdzie”; szczegółowe zestawienia liczbo- 
we wystapień znajdują się w aneksie) i przestrzennym (malarskie metafory przestrzenne). Choć tematem książki są prezentacje fotograficzne i malarskie, to nie brakuje przykładów z rzeźby, filmu, architektury, poezji, toponimii czy politycznych rytuałów.

Badania Plampera wpisuja się w ugruntowane interdyscyplinarne programy badawcze. Przyjęcie takiej strategii sprawia, że wąsko zakreślony temat książki - wizerunki Józefa Stalina w malarstwie i fotografii w latach 1929-1953 w Rosji Radzieckiej - jest problematyzowany w szerokich i zróżnicowanych perspektywach. Przedstawienia Stalina stają się przejawem nowożytnego kultu jednostki, pierwiastkiem rosyjskiej kultury, wytworem propagandy i przykładem ikonologii politycznej. Każda odpowiedź ma charakter cząstkowy, mówi o pewnych czynnikach kształtujących kult, pomijając inne. Dopiero połączenie ich wszystkich wyjaśnia powstanie niezwykłego kultu, pobudzającego wyobraźnię milionów ludzi - nie tylko w Związku Radzieckim, ale i na świecie: „Czystym zyskiem był Stalin, który wydawał się większy - i faktycznie odmienny - niż w rzeczywistości” (tamże: 26).

\section{/// Nowoczesna deifikacja władzy}

Początek kultu Stalina można usytuować bardzo dokładnie w czasie na grudzień 1929 roku, gdy sowiecki przywódca kończył 50 lat, a reżimowa gazeta „Prawda” przez kilka dni poświęcała temu wydarzeniu obszerny materiał. Wówczas było to zdarzenie odizolowane. O początku nieprzerwanego kultu można mówić dopiero trzy lata później. Kult jednostki jest zjawiskiem społecznym, którego przyczyn należy poszukiwać również poza kontekstem wąsko pojętych zabiegów politycznych i propagandowych.

Zagadnienia indywidualizacji, zaniku tradycyjnych wspólnot i narodzin społeczeństw nowoczesnych stanowiły podstawę dla projektu socjologii i filozofii społecznej końca XIX i początku XX wieku. Po dziś dzień są to zagadnienia należące do centrum socjologicznych zainteresowań. Do tych wątków nawiązuje Plamper, rysując drogę do kultu Stalina w Związku Radzieckim. Społeczne podstawy kultu autor widzi z jednej strony w uniwersalnych dla ówczesnej Europy, w tym Rosji, zjawiskach sakralizacji istoty ludzkiej w następstwie oświecenia i rewolucji francuskiej oraz przemianach źródła legitymizacji władzy. Z drugiej, w rosyjskich partykularyzmach: kulcie cara i bolszewickich formach organizacji partyjnej - kółkach (kru§̌kach) - skupiających działaczy politycznych wokół przywódcy. 
Napoleon III był pierwszym przywódcą otoczonym kultem w nowożytnym sensie. Doszedł do władzy w wyniku wyborów będących konsekwencją Wiosny Ludów, a po zamachu stanu w 1851 roku został ogłoszony cesarzem Francuzów. Inaczej niż w wypadku królów, źródłem legitymizacji cesarza był lud i plebiscyty, a nie prawo boskie. Lud stał się autorem moralnych i prawnych zasad. Napoleon III szukał bezpośrednich więzów z narodem i masowej aprobaty tłumów. Służyć temu miał zespół spektakli, parad, mitów i symboli, rozpowszechnianych za pomocą dostępnych środków przekazu. Uwolniona energia sakralna krążąca wśród ludu (narodu) przyległa w końcu do jednej postaci, prowadząc do jej deifikacji.

W XIX-wiecznej Francji sacrum zostało przeniesione ze sfery religijnej do sfery polityki. Bratanek Napoleona sytuował jednak swoją osobę powyżej bieżącej polityki partyjnej. System, który stworzył, tzw. bonapartyzm, zasadnie można uważać za nowoczesną dyktaturą demokratyczną. Zwierzchnikiem władzy nie jest Bóg czy wyróżniona warstwa społeczna (arystokracja, aparat urzędniczy), lecz cały naród, który sprawuje władzę zwierzchnia. Jednostki obdarzane kultem podkreślały swój związek z ludźmi, a zarazem były ponad ten lud wywyższane. Władza pochodząca z ludu odzwierciedlała społeczne nierówności, dlatego obiektem kultu musiał być mężczyzna. Naród poddawany był socjalizacji do bycia odbiorcą kultu przez armię, szkolnictwo, masowe widowiska i wydarzenia, jak obchody urodzin Napoleona I.

Kult Napoleona III odsłania cechy współczesnych kultów jednostek, różniące się od kultu przedmodernistycznego: zwierzchność ludu, sekularyzm, patrycentryzm, korzystanie ze środków masowego przekazu i ograniczenie do społeczeństw zamkniętych. Cechy te spełniały III Rzesza Niemiecka, Włochy Benito Mussoliniego czy Związek Radziecki, ale też w pewnym zakresie Polska Józefa Piłsudskiego. Wreszcie polityka wizerunkowa Franklina Roosevelta czy Ronalda Reagana posiadają ważne cechy wspólne z kultem jednostki. Jak zauważa Plamper (tamże: 45) odnośnie do kultu Mussoliniego: „Należy uznać [kult Mussoliniego] [...] za jeden z wariantów powszechnie znanej odpowiedzi na dylematy modernizacji, które po wojnie dręczyły wszystkie narody rozwinięte: anonimowość w coraz szerszych kontaktach społecznych wykraczających poza małe grupy (rodzina, wieś), wymuszonych przez uniwersalne instytucje - szkołę i armię oraz nowoczesne środki komunikacji (drogi, koleje, telegraf, telefon i radio), a także pamięć o Gemeinschaft skupionej wokół symbolicznej dla polityki przedwojennej monarchii”. 
Dla rozwoju kultu jednostki zasadnicze znaczenie miała I wojna światowa, która mobilizowała nie tylko wojsko, ale całe społeczeństwa. Kobiety i mężczyźni ze wszystkich klas albo walczyli na froncie, albo pracowali na tyłach armii. Rodząca się po wojnie kultura konsumpcyjna skierowana była do wszystkich ludzi: produkowane towary miały zacierać różnice klas, płci i rasy. Zhomogenizowane społeczeństwo paradoksalnie dowartościowało jednostkę. Wybicie się z tłumu stało się obiektem pożądania. Pozostaje antynomią nowoczesności łączenie uniwersalizmu z indywidualizmem, dążenie do równości i przebicie zasłony anonimowości.

\section{/// Historia carskiej Rosji i Związku Radzieckiego}

Szczególną wersję uniwersalnej historii sakralizacji jednostki przez lud reprezentują losy carskiej Rosji, ruchu bolszewickiego i wreszcie - Związku Radzieckiego. Car Aleksander III, panujący od 1881 do 1894 roku, zastąpił sposób legitymizacji władzy przez społeczeństwo, w tym wykształcone elity, realizowany przez swojego poprzednika Aleksandra II, zwrotem ku mistycznie pojętemu narodowi. W skład narodu wchodziły zarówno różne grupy etniczne, jak i warstwy społeczne, w tym chłopi. Szczególną funkcję pełniło prawosławie, które miało pomóc carowi stworzyć bezpośrednią więź z chłopstwem, z pominięciem dworu, który był postrzegany jako skompromitowany. Stworzenie ogólnie dostępnych realistycznych przedstawień cara, gazety skierowanej do chłopów i ceremonii pozwoliło stworzyć mit więzi między carem a ludem. W mit uwierzyli przede wszystkim sam car i jego otocznie.

Mit stworzony przez Aleksandra III rozwinął, doprowadzając do ekstremum, Mikołaj II. Wyłączył z pośrednictwa między monarchą a ludem nie tylko elity, ale również aparat administracyjny. Ceremonia koronacji w 1881 roku była nie tylko konsekracją monarchii, ale również samego monarchy jako bożego wybrańca. Car poszukiwał związków z narodem przez charyzmatycznych świętych wywodzących się z ludu (z Rasputinem na czele), z pominięciem popów, rytuałów i instytucji. Starał się o pełną, autokratyczną władzę, co zderzyło się z odwrotnymi tendencjami tych grup społecznych, które dążyły do zwiększenia udziału w życiu politycznym. Mit pozwalał wierzyć władzy, że rewolucja 1905 roku była robota wrogów - Żydów i rewolucjonistów - którzy sprowadzili „dobry” lud na zła drogę. Kolejnymi elementami kultu cara stała się „polityka historyczna" - obchody rocznic bitwy pod Połtawą i Borodino oraz trzechsetlecia dynastii Romanowów. 
Mikołaj II, uczestnicząc od 1905 roku w masowej grze politycznej, zaczął rywalizować o poparcie z Dumą. Okazało się to ruchem autodestrukcyjnym, ponieważ odarło monarchę z cech sakralnych. Kolejnymi elementami, które prowadziły do delegitymizacji cara w oczach ludu, było nieudolne dowodzenie przez niego armią w trakcie pierwszej wojny światowej. Wraz z rewolucją nastapiło „przeniesienie carskie”: forma deifikacji jednostki pozostała taka sama, zmienił się jednak jej obiekt. Naród przestał czcić cara, a zaczął przywódców rewolucji.

Choć tradycja marksistowska ma charakter kolektywistyczny, to zarówno carska tradycja, jak i sposób organizacji ruchu bolszewickiego sprzyjały pojawieniu się po raz kolejny jednostek otoczonych kultem. Rewolucyjny rok 1917 spowodował załamanie systemu władzy monarchicznej i akcję niszczenia kultu cara, lecz bardzo szybko zaczęły powstawać nowe kulty. Najpierw Aleksandra Kiereńskiego i Ławra Korniłowa, które jednak miały charakter ograniczony i krótkotrwały. Gdy rewolucja październikowa uczyniła marksizm oficjalną ideologia państwową, obiektem kultu stali się Karol Marks i Fryderyk Engels. Większość działaczy bolszewickich wywodziła się z warstwy inteligenckiej, która organizowała swoją działalność polityczną w kółkach (krù̌kach), na czele których stał zazwyczaj silny przywódca. Liderzy ci spełniali ważne funkcje materialne, psychologiczne i grupotwórcze wobec swoich podopiecznych. Szeregowi członkowie kółek wysławiali w zamian przywódców za pomocą sztuki. Jak zauważa Plamper (tamże: 45): „Gloryfikowanie przywódcy było dla nich doświadczeniem, które ich kształtowało, i większość nadal działała w ten sposób po objęciu władzy, pomimo wszystkich wyrazów niechęci dla kultu jednostki w ich retoryce". Relacja między przewodniczącym kółka a jego członkami przyjmowała niejednokrotnie charakter mecenatu nad artystami.

Kolejnym obiektem kultu został Włodzimierz Lenin. Stało się to jednak dopiero po jego śmierci w 1924 roku, wcześniej cieszył się zaledwie najwyższym uznaniem. Związane to było z decyzją o zabalsamowaniu ciała Lenina i budowie mauzoleum na jego cześć, która zresztą nie była akceptowana ani przez jego żonę, ani przez część partyjnych przyjaciół. Przyjęcie takiego rozstrzygnięcia uruchomiło powstawanie różnego rodzaju wytworów artystycznych, budujących kult: od masek pośmiertnych po film, zdjęcia, malarstwo, plakaty, rzeźbę itd. Kult zmarłego Lenina prowadzi już w sposób bezpośredni do kultu Stalina. Zwłaszcza na początku Stalin był ukazywany na przedstawieniach jako najbliższy współpracownik i kontynuator Lenina. 


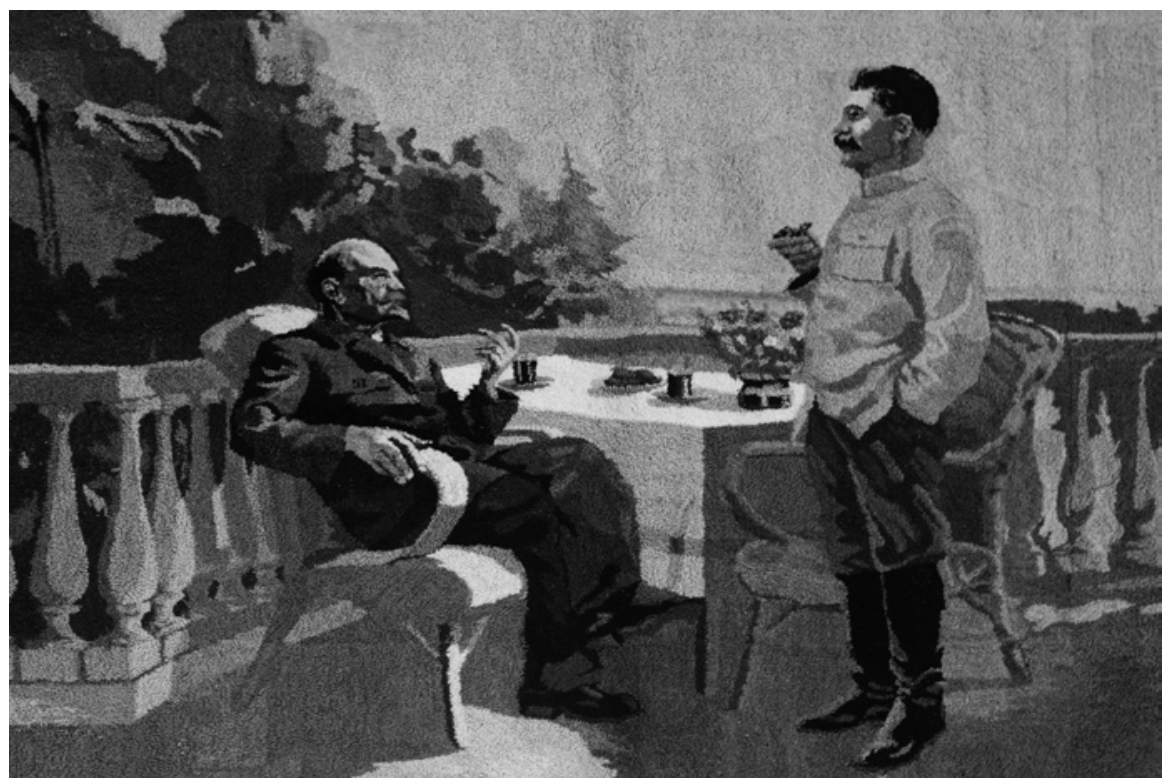

Il. 1. Lenin i Stalin. Muzeum Stalina w Gori, Gruzja. Fot. Kacper Motrenko.

Zastosowanie znajdowała tutaj zasada dynastyczna - Stalin miał być zgodnie z przekazem propagandowym namaszczony na rolę przywódcy. Do końca lat 30. ukształtował się kanon przedstawień i przedstawienia towarzyszace były coraz rzadsze. Stalin monopolizował wizerunek wodza, a na przedstawieniach występował w towarzystwie prostego ludu, zwłaszcza kobiet i dzieci. Jeśli pokazywano wodza z dziećmi, to zazwyczaj z dziewczynkami: „,różnica płci i wieku [...] podkreślały jeszcze bardziej, jak wysoko Stalin stał nad zwykłymi ludźmi” (tamże: 120).

Napięcie między ideologią kolektywistyczną a kultem Stalina znalazły wyraz w zinstytucjonalizowaniu ,nieskromnej skromności”. Z jednej strony, sam Stalin i podległy mu aparat dawali do zrozumienia, że skromność nie pozwala, aby wódz narodu pozował do obrazów i w ogóle poświęcał zbyt wiele czas sposobowi, w jaki był przedstawiany. Stalin był uważany za ,najskromniejszego z ludzi”, a tym samym stawał w opozycji do własnego kultu. Niechęć do pozowania była dla malarzy prawdziwym problemem. Trudno było im zachować prawdziwość odwzorowania bez szans na długi kontakt z modelem. Organizatorzy konkursów na portret Stalina musieli dostarczać artystom zdjęcia i materiały filmowe przedstawiające wodza jakoby pozującego na żywo. Z drugiej jednak strony, jak przekonująco pokazuje Plamper, opierając się na materiałach źródłowych, 
ściśle kontrolowano na najwyższych szczeblach władzy wizerunki Stalina w „Prawdzie”. Sekretariat wodza, a niekiedy on sam, akceptowali ukazujące się materiały.

Inne napięcie w sztuce socjalistycznej dotyczyło aktu twórczego: z jednej strony, działanie w nowym socjalistycznym ustroju, również działanie artystyczne, miało być prowadzone zgodnie z planem. Artyści mieli tworzyć sztukę na zamówienie władzy w celu propagowania komunizmu, przeznaczoną do kopiowania i masowej produkcji. Z drugiej strony, sami artyści często wyznawali romantyczny ideał spontanicznej i niezależnej inspiracji artystycznej. Organizatorzy wystaw też zresztą przedstawiali prezentowane dzieła jako spontaniczny efekt inicjatywy narodowej, pomimo dominującej roli państwa w ich powstawaniu.

Formuła twórczości artystycznej była w Związku Radzieckim złożona: w stalinowskiej kosmologii „artystę inspiruje Stalin, ucieleśnienie marksistowskiego rozwoju historycznego - tworząc sztukę przedstawiająca radziecki świat wraz z narodem jako tworem zmierzającym w stronę ostatniego historycznego etapu, kiedy upływ czasu zostanie zawieszony, a różnice między artystami, ludem i Stalinem przestaną mieć jakiekolwiek znaczenie" (tamże: 316-317). Taka filozofia twórczości wymagała odpowiedniej formy organizacyjnej: państwo finansowało nie tylko zakup gotowych dzieł, ale również cały proces produkcyjny. Na przykład aby artyści mogli poznać realia życia socjalistycznego, uczestniczyli w zorganizowanych wycieczkach do kołchozów i fabryk. Większość portretów Stalina powstawała w systemie kontraktowym.

Historia Związku Radzieckiego znajdowała odzwierciedlenie w ikonografii. Na początku lat 30. w gazetach dominowały przedstawienia wielkich przedsięwzięć industrialnych i infrastrukturalnych: pieców hutniczych, kominów, szybów naftowych, słupów elektrycznych itd. Od połowy lat 30. zaczęto mówić o osiągnięciu ustroju socjalizmu, co zostało wprost wypowiedziane w konstytucji z 1936 roku. Wertykalność została zastapiona horyzontalnością: pojawiły się widoki z lotu ptaka, panoramy miast socjalistycznych, ogrodów. W powieściach metafory maszynowe zostały zastąpione ogrodniczymi.

Jednym ze źródeł informacji dla kremlinologów na temat przywódców partyjnych, aktualnych sympatii i hierarchii wewnątrz aparatu była analiza fotografii ze spotkań ze Stalinem. Na tej podstawie oceniano aktualne wpływy i szanse na przejęcie schedy po wodzu. Po śmierci Stalina przez trzy kolejne dni był on pokazywany na fotografiach w trumnie: najpierw znajdującej się na pierwszym planie, potem oddalającej się coraz bardziej, 
co symbolizowało słabnącą władzę. Towarzysze otaczający ciało byli jego spadkobiercami. Gieorgij Malenkow zajmował miejsce najbliżej głowy, co znaczyło, że widziany był jako następca wodza. Ziściło się to jedynie częściowo.

Plamper szczegółowo analizuje, w jaki sposób wizerunek Stalina był wykorzystywany w cyklu rocznym przy różnego rodzaju świętach. Kalendarz świąt otwierała rocznica śmierci Lenina 2 stycznia (Stalin był ukazywany jako kontynuator jego myśli), następnie kolejno obchodzono Dzień Armii Czerwonej 23 lutego, Dzień Kobiet (to akurat nie było święto „stalinowskie" i wizerunek Stalina nie był reguła), 1 Maja, dzień prasy bolszewickiej 5 maja, Dzień Zwycięstwa, Wszechrosyjski Dzień Kultury Fizycznej, dzień marynarki wojennej ZSRR, Dzień Lotnictwa, rocznicę Wielkiej Rewolucji Październikowej, wreszcie - Dzień Konstytucji Stalinowskiej. W każdym z tych kontekstów w dniu święta lub w relacji ze święta następnego dnia zamieszczano wizerunki wodza. Drugorzędne święta, jak Dzień Lotnictwa, nie miały stałej daty i obchodzono je w ten sposób, żeby nie tracić dni pracy. Przedstawienia, na których pojawiał się Stalin, często były kanoniczne i co roku wykorzystywano te same.

\section{/// Propaganda - budowa kultu}

Badania z zakresu teorii komunikacji mają długą tradycję w empirycznych badaniach socjologicznych. Przed wybuchem drugiej wojny światowej nad radiosłuchaczami kanoniczne badania prowadził zespół Paula Lazarsfelda (Fleck 2011: 165-220). W trakcie wojny powstały liczne raporty zdające sprawę z morale swoich oraz wrogich amii i społeczeństw; siłą rzeczy dotyczyły również przekazu propagandowego (zob. Lazarsfeld, Merton 1982, Converse 1987: 162-185).

Najobszerniejszą część książki Plamper poświęca twórcom radzieckiej propagandy i jej odbiorcom. Klasycznie, propaganda rozumiana jest jako perswazyjny przekaz kierowany do opinii publicznej. Obok przemocy jest to najważniejsze narzędzie kontrolowania mas. W Kulcie Stalina autor zaciera różnicę między nadawcą przekazu perswazyjnego a odbiorcami. Po pierwsze, kult był co prawda nadzorowany centralnie, lecz kontrola nie miała charakteru absolutnego. Władza nad wytwarzanym kultem miała charakter rozproszony. Po drugie, adresaci propagandy, czyli obywatele Związku Radzieckiego, nie byli biernym odbiorca, lecz aktywnym twórca. Plamper podważa schemat komunikacyjny, w którym masy mogą albo przyjmować kierowane do siebie komunikaty, albo stawiać im opór. Ukazuje widzów 
jako podmioty elastyczne i zmienne, wrażliwe na kontekst historyczny i zdolne przyjmować różne myśli w tym samym czasie. W takiej perspektywie teoretycznej propaganda nie jest indoktrynacją obywateli przez władzę, lecz komunikatem powstającym w interakcji. Ostateczny sens konstytuuje się w licznych relacjach społecznych. Autor analizuje powstawanie wytworów kultu w sieci jednostek i instytucji.

Inaczej niż w nazistowskich Niemczech, w Rosji nie było jednego urzędu dbającego o wizerunek Stalina. Nie znaczy to, że nie można szczegółowo wskazać tych instytucji i ludzi, którzy odpowiadali w największym stopniu za wytwarzanie kultu: począwszy od politycznego szczytu (Stalina i Klimienta Woroszyłowa jako głównego mecenasa sztuki sowieckiej), poprzez instytucje organizujące pracę artystów, jak stowarzyszenia artystów i aparat partyjno-państwowy, instytucje edukacyjne, wydawnictwa i fabryki sztuk wizualnych, gazety i czasopisma, cenzura (Glawlit), aż po tajna policję. Wszystkie te instytucje tworzyły bardzo złożoną strukturę, w której poruszanie się stanowiło dla artystów wyzwanie i przedmiot niepisanej wiedzy. Stawką w grze były nie tylko prestiż czy pieniądze, ale również wolność i spokój.

Ze względu na fakt, że sztuka radziecka kierowana była do mas i miała nieść jasny przekaz propagandowy, twórcy kultu przypisywali duże znaczenie czytelności przekazu. Nie było podziału na sztukę tworzoną dla różnych grup czy klas społecznych. Każde dzieło sztuki powinno trafiać do wszystkich obywateli Związku Radzieckiego. Stąd też dążono do wytwarzania portretów kanonicznych: jednakowych i jednoznacznych dzieł służących kultowi. Aby ustalić kanon reakcji na wystawiane dzieła, władza potrzebowała informacji zwrotnej: uzyskiwała ja za pomoca ankiet socjologicznych, obserwacji prowadzonych przez psychologów czy ksiąg gości.

Plamper sięga do nietypowych dokumentów: ksiąg gości, w których odwiedzający wystawy zapisywali swoje uwagi. Dzięki temu możemy poznać nastroje publiczności. O ile na początku spełniały one funkcje statystyczne, mające pomóc ocenić frekwencję na wystawach, o tyle szybko stały się miejscem pisania peanów na cześć władzy. Prowadzenie statystyk nie tylko miało służyć celom poznawczym, ale także było przykładem „wojen statystycznych”. Ludzie, przychodząc na wystawy, „głosowali nogami” i legitymizowali sztukę socrealistyczną, a w konsekwencji i cały system władzy. Wyłożona w muzeum księga miała przekonać społeczeństwo, że sztuka jest tworzona dla ludu i przez lud. Księgi pełniły jednak również funkcje dydaktyczne: zwiedzający mogli się nawzajem edukować, studiując 
swoje wpisy. Była to próba stworzenia przestrzeni komunikacyjnej między widzami: jeden widz mógł czynić komentarze do uwag drugiego. Wreszcie, księgi miały służyć mobilizacji społecznej: „[U]czyły zwiedzających muzeum «mówić po bolszewicku» o sztukach pięknych, czyli dyskutować o obrazie, który właśnie oglądają" (Plamper: 340).

W kolektywistycznym systemie radzieckim opinia robotnicza miała wyznaczać kanony piękna. Księgi gości miały w związku z tym zastąić przedrewolucyjną krytykę sztuki. Niewykluczone, że rozstrzygnięcie sporu między realistami a modernistami na rzecz tych pierwszych dokonało się również pod wpływem ocen widzów zawartych w księgach gości i wyrażanych w socjologicznych ankietach. Ocena prac przez masy spotkała się jednak z oporem samych artystów. Lekceważono w związku z tym głosy krytyczne, twierdząc, że wystawę odwiedzaja głównie ,znudzeni spacerowicze”. Plamper (tamże: 326) zwraca uwagę na paradoks: „, [G]dy księgi gości stały się głównie "wsiami patiomkinowskimi», zaczęły być uważane za oznakę prawdziwego demokratycznego tworzenia sztuki”. Krytyczne oceny na wystawach stalinowskich były rzadkie: obrazy Staliny miały charakter ikon - czczono je, a nie oceniano. Nieprzychylne opinie były zresztą niejednokrotnie usuwane przez władze muzeów. Związki artystów dostrzegały również problemy logistyczne. Gdyby kierowano się przy wyborze dzieł do wystawiania opinia zwiedzających, to należałoby zadbać o klasową reprezentacyjność grupy, która musiałaby obejrzeć liczne prace zgromadzone w jednym miejscu.

Względy propagandowe wyjaśniają zmieniająca się częstotliwość pojawiania się Stalina w prasie - gdy działo się źle na froncie czy w relacjach wewnętrznych (czystki), wódz znikał, by powrócić z uśmiechem w momentach tryumfu. Na kanonicznym portrecie powojennym Stalin ma włosy posiwiałe, starczy podbródek, pogłębione zmarszczki na czole - cechy te wyrażają doświadczenia wojny i śmierci milionów ludzi.

Sztuka socrealistyczna, a zwłaszcza przedstawienia wodza, pełniły ważną funkcję legitymizacyjna. Wizualność odgrywała doniosłą rolę w kształtowaniu umysłowego wszechświata obywateli Związku Radzieckiego, których znaczna część była wciąż analfabetami. Współgrała z prawosławną tradycja pisania ikon, które również stanowiły obrazy performatywne.

\section{/// Ikonografia polityczna}

Badania Plampera wpisują się wreszcie w nurt ikonologii politycznej. W ciagu ostatnich dwóch dekad w naukach społecznych nastąił „zwro- 
tu ku wizualności” (pictorial turn (Mitchell 1995))1. Już nie tylko badania dokumentarne, sondaże czy analizy języka, lecz także malarstwo, fotografia, film czy rzeźba stały się materiałem empirycznych analiz. $Z$ tendencja w empirycznych badaniach społecznych spotkały się przemiany w łonie historii sztuki: narastało przekonanie, że badanie artystycznych artefaktów za pomoca kategorii formalno-estetycznych jest niewystarczające. Abstrahujące od kontekstu powstania (religijnego, politycznego, klasowego) nie daje szansy odkryć sensu przedstawianych dzieł. Jak zauważa Plamper (2014: 183), ,analityczne narzędzia nie potrafią zbadać portretu, który należałoby raczej czcić niż analizować". Przedstawienia Stalina miały charakter ikon, które przekazują światu ładunek świętości.

Dwie tendencje spotkały się w badaniach nad ideologiami totalitarnymi. Obok takich nośników ideologii, jak język (zob. np. Klemperer 1983, Orwell 2010, Głowiński 1993), mity (zob. np. Mosse 1972, von Krockow 2000), idee filozoficzne (zob. np. Aron 2000) czy postawy (zob. np. Adorno 2010, Kershaw 2009, Goldhagen 1999), w tym postawy intelektualistów (zob. np. Miłosz 1999, Judt 2012), wyodrębniło się coraz liczniej reprezentowane pole badawcze, które obiektem analiz uczyniło przedstawienia wizualne jako nośnik przekazu ideologicznego².

Plamper przyjmuje obok ekonomii prac historyka (rekonstrukcja faktów na podstawie źródeł) i socjologa (nadanie faktom sensu teoretycznego) perspektywę historyka sztuki. O ile łączenie historii z socjologia nikogo już nie dziwi, o tyle posługiwanie się kategoriami estetycznymi do opisu dzieł sztuki propagandowej może zaskakiwać. Zazwyczaj opisujemy je jako sztampowe, posługujące się prostym, zrozumiałym dla mas przekazem, których forma determinowana jest ideologicznie, a ich jedynym raison d'être jest ugruntowywanie pozycji władzy. Sztuka propagandowa miałaby być rodzajem antysztuki, która porzuca poszukiwanie piękna na rzecz realizacji celów politycznych. Podobnie jednak jak socjologiczne analizy ustrojów totalitarnych odrzuciły paradygmat ,negatywu historycznego” (Gentile 2011: 11), zgodnie z którym są one interpretowane jako zaprzeczenie postępu, nowoczesności, demokracji i wartości, tak zrozumienie sensu dzieł sztuki wymaga porzucenia dziewiętnastowiecznego ideału „sztuki dla sztuki”.

\footnotetext{
${ }^{1}$ Oczywiście nie jest tak, że analiza wizualna była wcześniej zupełnie nieobecna w badaniach społecznych, zwłaszcza w antropologii (zob. np. Bateson, Mead 1942, Collier 1967). Zwiększone zainteresowanie wizualnością znajduje również oddźwięk na polskim rynku wydawniczym (zob. np. Olechnicki 2003, Boguni-Borowska, Sztompka 2012, Banks 2013).

2 Dowodem rosnącego zainteresowania sztuka propagandową w Polsce są m.in. wystawa w Muzeum Narodowym w Krakowie Socrealižm. Grafika polska ₹ lat 1949-1954 (grudzień 2009-luty 2010), zbiór tekstów na temat plakatu wojennego (Ferenc i in. 2011) czy wydana w 2014 roku książka Joanny Studzińskiej Socrealizm w malarstwie polskim.
} 
Choć posługiwanie się formalnymi kategoriami estetyki pozwala odkryć techniczną biegłość artystów, to odcina ich prace od kulturowego uniwersum znaczeń. Plamper traktuje poważnie sztukę propagandową, ukazując jej istotne miejsce w kreowaniu krajobrazu politycznego.

Niechęć między sztuką propagandową a krytyką sztuki jest obustronna. Z jednej strony, sztuka ideologiczna ma charakter ekspansywny - ma zupełnie „pochłonać” widza. W państwie totalitarnym oficjalna krytyka sztuki nie istnieje, bo wymaga dystansu i możliwości odrzucenia jakichś wytworów. Przedstawienia Stalina czczono, a nie oceniano. Po drugie, przyjęcie (pozornie) uniwersalnych kryteriów nakazywałoby o przedstawieniach propagandowych nie wspominać wcale. Dzieła sztuki propagandowej nie mają reprezentować świata lub idei (funkcja kognitywna) czy uczuć artysty (funkcja ekspresywna), lecz wywierać wpływ (funkcja performatywna). Krytyczna analiza wytworów propagandy musi uwzględniać ich specjalny, konstruujący rzeczywistość charakter. Znaczenie dzieła konstytuuje się w sieci między artystami, mecenasami, instytucjami organizującymi prace artystów oraz opinią publiczna. Obraz nie jest jedynie dziełem sztuki, ale również elementem rytuałów i symboli politycznych.

Pole badawcze ikonografii politycznej ukonstytuowało się na początku lat 90. w Hamburgu i wzięło sobie za patrona Aby'ego Warburga ${ }^{3}$. Niemieccy badacze poszukiwali autonomii swoich badań w przedmiocie: strategiach wizualnych wykorzystywanych do legitymizacji władzy. Inaczej niż w studiach nad propaganda, badacze mniej koncentrują się na taktyce graczy politycznych, a bardziej na funkcjonowaniu instytucji i konfiguracjach historycznych ${ }^{4}$. Książka Plampera jest empiryczną realizacją tych założeń: ukazuje dynamiczny proces konstruowania znaczeń dzieł propagandy.

Plamper posługuje się koncepcją Edwarda Shilsa (1975), zgodnie z którą każde społeczeństwo posiada swoje centrum - będące rzeczą z porządku symboli, wartości i przekonań - które nim rządzi. Centrum jest również zjawiskiem z porządku działania - jest to struktura działań, ról i osób w sieci instytucji. Naturą centrum jest świętość i w tym sensie można powiedzieć, że każde społeczeństwo posiada jakąś oficjalną religię, nawet jeśli jest ono postrzegane jako sekularne, pluralistyczne i tolerancyjne. Plamper (2014: 20) podkreśla, że pojęcie centrum i sakralności dobrze oddaje „echa, ślady i ponowne wprowadzenie religii we współczesnym, rzekomo «po-

\footnotetext{
3 Zwięzłego podsumowania programu ikonologii politycznej dokonał Christian Joschke (2012).

4 Przykładem znanej pracy powstałej w ramach tradycji ikonografii politycznej jest książka Horsta Bredekampa (2003) dotycząca obrazu lewiatana, który miał reprezentować nowoczesne państwo.
} 
zbawionym magii» świecie" $e^{5 \prime}$. Posłużenie się socjologiczną koncepcją Shilsa pozwala widzieć fenomen kultu Stalina jako zjawisko z dwóch porządków: semiotyki kulturowej i działań racjonalnych aktorów w ramach społecznych instytucji. Celem Plampera jest $z$ jednej strony ukazanie procesu wytwarzania centrum, a z drugiej - analiza ukonstytuowanych znaczeń. Wśród powracających w różnych miejscach książki motywów charakterystycznych dla Sowieckiej Rosji można wymienić następujące:

Centralność. Postać Stalina stanowiła centrum społeczeństwa: była punktem odniesienia w porządku społecznym, symbolicznym i kulturalnym. Wódz to punkt promieniujący energią sakralną. Kreml, Moskwa, Partia, Związek Radziecki i naród stanowiły koncentryczne kręgi wokół Stalina. Znajdowało to wyraz na przykład w planie urbanistycznym Moskwy - zamiast porządku osiowego (jak Petersburg), rosyjska stolica rozrastała się koncentrycznie wokół Kremla, co podkreślił plan z 1935 roku.

Stalin urzędował w Moskwie, ale jego obecność można było dostrzec wszędzie. Alpiniści zdobywszy Szczyt Stalina - najwyższą górę Związku Radzieckiego - ustawili tam popiersie swojego wodza. W trakcie wojny naród wzywany był do skupienia się wokół generalissimusa, a apel drukowany w „Prawdzie” ilustrowany był zdjęciem robotników zebranych wokół popiersia Stalina. Wyprawa badaczy-pilotów do Ameryki przez biegun północny, z centrum na peryferie i z powrotem, podbudowywała ideę centrum. Piloci relacjonowali w „Prawdzie”:

Wystartowaliśmy ze szczołkowowskiego lotniska i skierowaliśmy samolot na biegun północny. Od tej chwili przez cały czas nasze myśli wracały ku Moskwie. Za każdym razem, gdy podczas lotu musieliśmy przezwyciężyć różne trudności, myśleliśmy o Stalinie, który pracuje w centrum Moskwy (cyt. za Plamper 2014: 150).

Znajdowało to wyraz również w reprezentacjach wizualnych: „wytwory kultu lokowały go [Stalina] w środku sceny, a inne osoby i obiekty zaczęły się gromadzić w kręgach wokół niego, czyli wokół centrum" (tamże: 145). Pejzaże czy martwa natura jako gatunki zostały zdewaluowane na rzecz portretu. Stalin był postacią wyróżnioną na obrazie czy zdjęciu przez kolor ubioru, charakterystyczną sylwetkę czy spojrzenie, umiejsco-

\footnotetext{
5 Autor posługuje się za Maxem Weberem pojęciem „odczarowywania” [disenchantement], co niezręcznie zostało przełożone przez tłumaczy książki. Rzecz jest najwyższej wagi: Plamper posługuje się pojęciem sakralności w kontrze do teorii sekularyzacji, które widzą nowoczesność jako pozbawioną świętości. Tymczasem wybitnie nowoczesne państwo ufundowane na antyreligijnej ideologii działa zgodnie z normami religii.
} 
wienie na płótnie, rozmiar postaci, grę światłem itd. Wraz z umacnianiem się wodza w centrum kultury wizualnej, coraz rzadziej był on przedstawiany w grupie.

Świętość. Stalin stanowił uosobienie świetlanej przyszłości, z którą dzięki przedstawieniom - można było stanąc twarzą w twarz. Wewnątrz murów Kremla nie było przedstawień antropomorficznych w obawie przed sakralnym podwojeniem - święte centrum może być tylko jedno i był nim Stalin. Gdy po trzyletniej przerwie, w 1933 roku, wizerunki Stalina zagościły z powrotem na łamach „Prawdy”, ograniczono wizerunki innych typów. Działo się tak, mimo że kultura indywidualistyczna zagościła już w Związku Radzieckim, co widać było w pojawieniu się zjawiska gwiazd filmowych czy kulcie przywódców partyjnych (obchody 50. urodzin Woroszyłowa w 1931 roku).

Gloryfikacji dostępowali jednak również bohaterowie pracy socjalistycznej - stachanowcy, a później także przedstawiciele świata nauki, jak Iwan Pawłow, czy kultury, jak Aleksander Puszkin, Taras Szewczenko czy Nikołaj Gogol. Te postacie nie były świętymi samymi w sobie, lecz świeciły światłem odbitym. Ich wizerunki pozostawały w dialogu ze Stalinem. Kult bohaterów wzmacnial jeszcze bardziej świętość samego wodza, który znów obdarzał świętością bohaterów. Jak stwierdza Plamper (tamże: 82): „[Z]estalinizowany Puszkin wzmocnił władzę Stalina, a spuszkinizowany Stalin wsparł potęgę literatury". W przedstawieniach wizualnych przybierało to nieraz wyraz bardzo dosłowny: Puszkin występował na przykład w płaszczu Stalina, a popiersie wodza przypominało Gogola.

Zestawienie faktów z dziedziny politycznej i religijnego języka opisu nie jest przypadkowe. Plamper dostrzega ważną ciagłość między tymi dziedzinami. Dobrze oddaje też charakter doświadczenia politycznego wyrywa politykę z dziedziny decyzji podejmowanych w wyniku kalkulacji indywidualnych użyteczności, widząc przede wszystkim wymiar rytuału, tradycji i emocji.

Bezruch. Sakralność Stalina podkreślana była przez bezruch i wielkość przedstawień. Wódz był centrum Związku Radzieckiego, które z definicji nie porusza się. W poezji znajdowało to wyraz w metaforze słońca używanej na określenie Stalina - Związek Radziecki krążył wokół swojego wodza.

Ważnym tropem występującym w ikonografii Stalina jest podkreślanie jego stateczności i spokoju. Artyści korzystali z genderowego kodu, zgodnie z którym mężczyzna jest utożsamiany z siła, umysłowością i rozumem. Stalin występował często w otoczeniu kobiet i dzieci, co pozwalało podkreślać jego męskie cechy. Lenin był przedstawiany jako postać dynamicz- 
na, w ruchu, ucieleśnienie rewolucji, podczas gdy Stalin - jako rewolucja zrealizowana. Dlatego na obliczu Stalina rysował się spokój, widoczna ufność w powodzenie sprawy, której przewodził, wiara w swoje własne siły. Lenin był zazwyczaj przedstawiany po stronie lewej, utożsamiał początek i kobiecość, Stalin zaś po prawej - wyrażając męskość i koniec.

Wyraźnie widać grę znaczeń między różnymi XX-wiecznymi dyktatorami: Hitler miał w sobie emocjonalny pierwiastek, Mussolini był artysta lepiącym z feminizowanych mas, a Stalin stanowił ucieleśnienie postępu technicznego i społecznego: industrializacji i kolektywizacji.

Naród. Stalin wyrażał skomplikowaną radziecką tożsamość. Każdy mieszkaniec Związku Radzieckiego był obywatelem federacji, a zarazem przedstawicielem etnoterytorialnych jednostek. Silny charakterystyczny akcent Stalina czy zwyczaj wskazywania osoby do toastu silnie kojarzyły się z gruzińskością. Wódz był jednak „ojcem narodów”, dlatego przedstawienia, zwłaszcza od wojny, unikały akcentowania jego etnicznego pochodzenia. Zwrot ku „radzieckiemu patriotyzmowi” podkreślony został na przykład przez obecność na fotografiach dziewczynek z warkoczem i jasnowłosych chłopców, reprezentujących kwintesencję rosyjskości, w miejsce dzieci $z$ innych etnicznie regionów.

Na znanym obrazie Stalina i Woroszyłowa na Kremlu z 1938 roku pierwszy utożsamiał naród radziecki rozumiany jako ciało polityczne, a drugi - Armię Czerwoną chroniącą wodza i naród. Gdy w trakcie wojny Stalin zaczął występować w mundurze wojskowym, przejął również rolę najwyższego wodza reprezentującego armię.

Wzrok. Spojrzenie Stalina wyrażać miało jego geniusz i siłę, a zarazem więź z narodem. Plamper (tamże: 16) przytacza anegdotę, jak grupa moskiewskich studentów, weteranów wojennych, odwracała portret Stalina w stronę ściany, żeby móc swobodnie rozmawiać o przeżyciach z frontu. Był tym elementem, na którym artyści skupiali szczególną uwagę w trakcie spotkań z wodzem, widząc w nim jego geniusz. Obrazy i fotografie tworzyły kolisty układ wyobrażeń - wyrażało to kult Stalina i przekonanie o jego świętości. Często jedynie wzrok wodza wybiegał poza obręb obrazu, ukazując pewne spojrzenie w przyszłość, w której zrealizowany miał zostać komunistyczny ideał organizacji życia społecznego. W samym wodzu następowało ucieleśnienie sił historycznych, które miały doprowadzić do realizacji utopii na Ziemi. Plamper (tamże: 46) przywołuje porównanie ponurego Hitlera, w którego magnetycznym wzroku tkwił antyracjonalny element narodowego socjalizmu, i Stalina, którego spojrzenie wyrażało radziecki program oświeceniowy. 


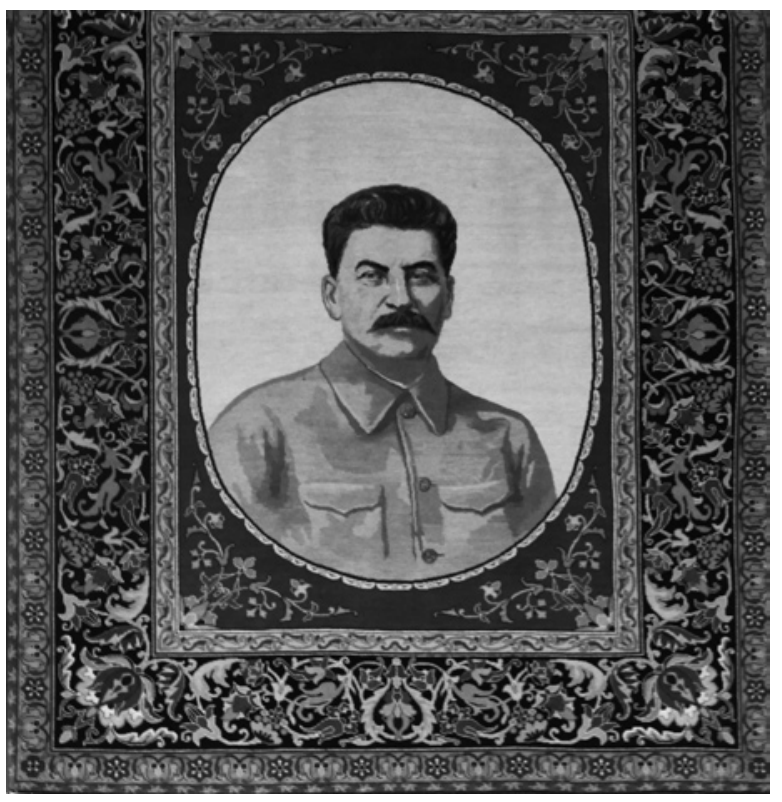

Il. 2. Wzrok Stalina skierowany poza obręb obrazu. Muzeum Stalina w Gori, Gruzja.

Fot. Kacper Motrenko.

Nieobecna obecność. Od połowy lat 30. Stalin pojawiał się coraz częściej na obrazach samotnie lub przez sygnalizowanie obecności za pomoca obrazu, rzeźby czy fotografii wodza w tle malowidła. Bywało, że granice między fotografią, malarstwem i rzemiosłem ludowym zacierały się. Na jednym z obrazów widzimy scenę, gdzie tkaczki wykonują portret Stalina według otrzymanej fotografii. Gdy po zwycięskiej drugiej wojnie światowej nastąiła pełna apoteoza przywódcy Związku Radzieckiego,

Il. 3. Niekanoniczne jeszcze

przedstawienie Stalina. Muzeum Stalina w Gori, Gruzja. Fot. Kacper Motrenko.

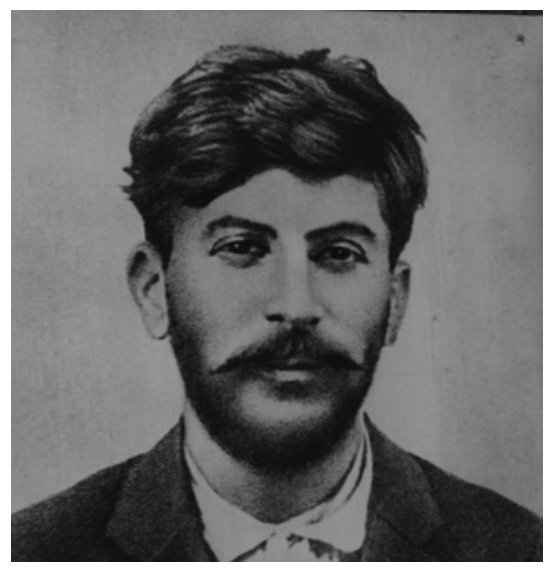


obecność Stalina widoczna była na radosnych twarzach ludzi zgromadzonych wokół radia, chłopców wracających z demonstracji czy kobiety, która wróciła ze spotkania ze Stalinem do swojej kaukaskiej wsi. Jest to przykład „nieobecnej obecności”. Plamper (tamże: 106) podsumowuje, że „będąc nieobecnym, Stalin stał się bardziej obecny niż kiedykolwiek wcześniej”.

Stworzenie czytelnej symboliki i wypracowanie kanonicznych przedstawień postawiły pod znakiem zapytania dalszy rozwój sztuki. Artyści stanęli przed wyzwaniem pogodzenia postępu, który wpisany był w marksistowską ideologię, z zastanym kanonem ikonograficznych przedstawień. Był to również spór między realizmem obrazów, dla których kryterium wierności była pamięć świadków historii, z zakorzenionymi w pamięci zbiorowej wyobrażeniami, które ukształtowały ikonografię - jej naruszenie było zamachem na świętość.

Zasadnicza część książki oparta jest na pracy źródłowej: w sposób atrakcyjny dla czytelnika zestawione są liczne fakty i anegdoty. Miejscami dzieje się to kosztem systematycznego przedstawienia problematyki. Choć na pierwszy rzut oka zamysł konstrukcyjny książki jest klarowny, to czytając, tracimy poczucie pewności. Wiele pojęć i interpretacji powtarza się wielokrotnie (centralność, świętość, wzrok Stalina skierowany poza ramy zdjęcia czy obrazu, powiązanie wystąpień Stalina w prasie z historia polityczna, performatywna rola obrazów itd.). Choć zabieg Plampera jest celowy - pragnie przedstawić gęsty opis przedmiotów i powiązanych z nimi praktyk, których wynikiem jest Stalin jako jednostka otoczona kultem to fakt, że nie zdecydował się na którąs ścieżkę interpretacyjną (np. w ramach któregoś z wyżej wymienionych pól badawczych) sprawia wrażenie deficytu teorii. Autorowi udałoby się sformułować bardziej nośne wnioski ogólne, gdyby organizacja empiryczna materiału została zastapiona organizacją teoretyczną. Oprócz znakomitego rozdziału pierwszego dotyczącego nowożytnego kultu jednostki pozostałe zorientowane są na empirię. Służą prezentacji zebranego przez Plampera materiału historycznego dotyczącego kolejno przedstawień Stalina w „Prawdzie”, w malarstwie socrealistycznym, patronatu w sztuce, instytucji wytwarzających kult i ksiagg gości. We wstępie Autor przedstawił za Shilsem pojęcie świętości jako centralne dla całej książki i szkoda, że nie był w tym konsekwentny do końca. Mogłoby ono nie tylko stanowić ważne i powtarzające się odwołanie, ale także ramę dla całego dzieła. Zamiast konsekwentnie je rozwinąć, bazuje na intuicyj- 
nych skojarzeniach. W konsekwencji książka ma bogaty repertuar odwołań teoretycznych, ale ostatecznie jest eklektyczno-empiryczna.

Powyższa uwaga nie zmienia faktu, że książka stanowić może inspirację również dla kolejnych badań. Plamper przypomina, że kult Stalina był fenomenem międzynarodowym. Każdy z krajów bloku wschodniego wytwarzał jego specyficzną odmianę. Mariusz Szczygieł (2006) przypomniał historię (również post mortem) największego na świecie pomnika Stalina w Pradze, który wznosił się nad Wełtawą aż do 1962 roku. Z kolei organizacja „Głos” planowała w 1970 roku podpalenie Muzeum Lenina w Poroninie i wysadzenie pomnika wodza rewolucji. Sam Autor, odnosząc się do Polski, wspomina obchodzenie urodzin Bolesława Bieruta na kształt urodzin Stalina czy przyznawanie wodzowi Związku Radzieckiego honorowego miejsca w różnych komitetach.

Praca Plampera pozwala myśleć także o badaniach przekraczających historię sztuki komunistycznej. Polskim fenomenem jest kult Jana Pawła II, znajdujący swój bogaty wyraz w sztuce czy toponimii. Z perspektywy krytyka sztuki niewiele przedstawień polskiego papieża zasługuje na uwagę. Odtworzenie jednak ich historii, sensu i ekonomiki powstawania może być znakomitym zadaniem dla socjologa. Podobnie zresztą można analizować inne przejawy współczesnej sztuki sakralnej, jak Sanktuarium w Licheniu czy figurę Jezusa Chrystusa Króla Wszechświata w Świebodzinie.

Kult Stalina jest udanym połączeniem pracy źródłowej historyka z perspektywą socjologa i historyka sztuki. Dzięki osadzeniu kultu zdjęć i obrazów w szerokim kontekście instytucjonalnym i kulturowym rozumiemy, jak złożonym i rozległym był on zjawiskiem. Zarazem Plamper daje do zrozumienia, że dochodzi do granic zrozumienia:

Im bardziej się weń [kult] wpatrywałem, tym trudniej było mi go dostrzec. Zastanawiałem się, jak zrozumieć kobietę, która mdleje na widok Stalina, pisarza uznawanego za jego przeciwnika, który wpada niemal w ekstaze, gdy staje blisko prawdziwej postaci, przyszłego dysydenta, który cierpi z powodu koszmarów o otruciu wodza, ofiary brutalnej polityki, które umierają na zawał na wieść o zgonie jej twórcy (Plamper 2014: 26).

Okazuje się, że w ostatecznym rozrachunku nie jesteśmy w stanie pojąc innych ludzi, miejsc i czasów. Możemy natomiast wiernie zdać z nich sprawę za pomocą trafnie dobranych pojęć i w tym należy widzieć zasługę Plampera. 
Bibliografia:

/// Adorno T.W. 2010. Osobowość autorytarna, tłum. M. Pańków, Wydawnictwo Naukowe PWN, Warszawa.

/// Aron R. 2000. Opium intelektualistón, tłum. Czesław Miłosz, Muza, Warszawa.

/// Banks M. 2013. Materiały wizualne w badaniach, tłum. P. Tomanek, Wydawnictwo Naukowe PWN, Warszawa.

/// Bateson G., Mead M. 1942. Balinese Character. A Photographic Analysis, New York Academy of Sciences, New York.

/// Boguni-Borowska M., Sztompka P., red. 2012. Fotospoleczeństwo. Antologia tekstów z socjologii wižalnej, Wydawnictwo Znak, Kraków.

/// Bredekamp H. 2003. Thomas Hobbes. Der Leviathan. Das Urbild des modernen Staates und seine Gegenbilder. 1651-2001, Akademie-Verlag, Berlin.

/// Collier J. 1967. Visual Anthropology. Photography as a Research Method, Holt, Rinehart and Winston, New York.

/// Converse J.M. 1987. Survey Research in United States. Roots and Emergence 1890-1960, University of California Press, Berkeley, Los Angeles, London.

/// Ferenc T., Dymarczyk W., Chomczyński P., red. 2011. Socjologia wiæualna w praktyce. Plakat jako narzedzie propagandy wojennej, Wydawnictwo Uniwersytetu Lódzkiego, Łódź.

/// Fleck Ch. 2011. A Transatlantic History of the Social Science. Robber Barons, the Third Reich and the Invention of Empirical Social Research, tłum. H. Beister, Bloomsbury Academic, London, New York.

/// Głowiński M. 1993. Peereldiada. Komentarze do slów 1976-1981, Państwowy Instytut Wydawniczy, Warszawa.

/// Goldhagen D.J. 1999. Gorliwi kaci Hitlera. Zwyczajni Niemcy i Holocaust, tłum. W. Horabik, Prószyński i S-ka, Warszawa.

/// Judt T. 2012. Historia niedokończona. Francuscy intelektualisci 1944-1956, tłum. P. Marczewski, Wydawnictwo Krytyki Politycznej, Warszawa.

/// Joschke Ch. 2012. À quoi sert l'iconographie politique?, „Perspective. Art et Pouvoir", nr 1. 
/// Kershaw I. 2009. Mit Hitlera, tłum. J. Lang, Wydawnictwo Replika, Zakrzewo.

/// Klemperer V. 1983. LTI. Notatnik filologa, tłum. J. Zychowicz, Wydawnictwo Literackie, Kraków.

/// Lazarsfeld P.F., Merton R. 1982. Studia nad propaganda radiowa i filmowa, [w:] R.K. Merton, Teoria socjologiczna i struktura społeczna, tłum. E. Morawska i J. Wertenstein-Żóławski, Wydawnictwo Naukowe PWN, Warszawa.

/// Miłosz Cz. 1999. Zniewolony umysł, Wydawnictwo Literackie, Kraków.

/// Mitchell W.J.T. 1995. Picture Theory, University of Chicago Press, Chicago.

/// Mosse G.L. 1972. Kryzys ideologii niemieckiej, tłum. T. Evert, Czytelnik, Warszawa.

/// Olechnicki K. 2003. Antropologia obrazu. Fotografia jako metoda, przedmiot i medium nauk społecznych, Oficyna Naukowa, Warszawa.

/// Orwell G. 2010. Rok 1984, Wydawnictwo Muza, Warszawa.

/// Plamper J. 2014. Kult Stalina. Studium alchemii władæy, tłum. K. Bażyńska-Chojnacka i P. Chojnacki, Świat Książki, Warszawa.

/// Studzińska J. 2014. Socrealizm w malarstwie polskim, Wydawnictwo Naukowe PWN, Warszawa.

/// Szczygieł M. 2006. Dowód miłości, [w:] tegoż, Gottland, Wydawnictwo Czarne, Wołowiec.

/// Sztompka P. 2012. Socjologia wizualna. Fotografia jako metoda badawcza, Wydawnictwo Znak, Kraków. 